University of Nebraska - Lincoln

DigitalCommons@University of Nebraska - Lincoln

USGS Staff -- Published Research

US Geological Survey

2014

Wetland Reserve Program Enhances Site Occupancy and Species Richness in Assemblages of Anuran Amphibians in the Mississippi Alluvial Valley, USA

Susan C. Walls

USGS National Wetlands Research Center, swalls@usgs.gov

J. Hardin Waddle

Stephen P. Faulkner

U.S. Geological Survey, faulkners@usgs.gov

Follow this and additional works at: http://digitalcommons.unl.edu/usgsstaffpub

Part of the Geology Commons, Oceanography and Atmospheric Sciences and Meteorology Commons, Other Earth Sciences Commons, and the Other Environmental Sciences Commons

Walls, Susan C.; Waddle, J. Hardin; and Faulkner, Stephen P., "Wetland Reserve Program Enhances Site Occupancy and Species Richness in Assemblages of Anuran Amphibians in the Mississippi Alluvial Valley, USA" (2014). USGS Staff -- Published Research. 817. http:// digitalcommons.unl.edu/usgsstaffpub/817

This Article is brought to you for free and open access by the US Geological Survey at DigitalCommons@University of Nebraska - Lincoln. It has been accepted for inclusion in USGS Staff -- Published Research by an authorized administrator of DigitalCommons@University of Nebraska - Lincoln. 


\title{
Wetland Reserve Program Enhances Site Occupancy and Species Richness in Assemblages of Anuran Amphibians in the Mississippi Alluvial Valley, USA
}

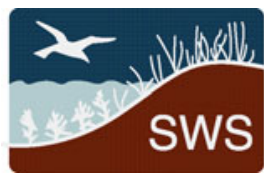

\author{
Susan C. Walls • J. Hardin Waddle • Stephen P. Faulkner
}

Received: 4 July 2013 / Accepted: 6 November 2013 /Published online: 3 December 2013

(C) US Government 2013

\begin{abstract}
We measured amphibian habitat use to quantify the effectiveness of conservation practices implemented under the Wetland Reserve Program (WRP), an initiative of the U.S. Department of Agriculture's Natural Resources Conservation Service. From February to June 2007, we quantified calling male anurans in cultivated cropland, former cultivated cropland restored through the WRP, and mature bottomland hardwood forest. Sites were located in two watersheds within the Mississippi Alluvial Valley of Arkansas and Louisiana, USA. We estimated detection probability and site occupancy within each land use category using a Bayesian hierarchical model of community species occurrence, and derived an estimate of species richness at each site. Relative to sites in cultivated cropland, nine of 11 species detected were significantly more likely to occur at WRP sites and six were more likely to occur at forested sites. Species richness estimates were also higher for WRP and forested sites, compared to those in cultivated cropland. Almost half (45\%) of the species responded positively to both WRP and forested sites, indicating that patches undergoing restoration may be important transitional habitats. Wetland Reserve Program conservation practices are successful in restoring suitable habitat and reducing the impact of cultivation-induced habitat loss on amphibians in the Mississippi Alluvial Valley.
\end{abstract}

S. C. Walls $\cdot$ J. H. Waddle $\cdot$ S. P. Faulkner

U.S. Geological Survey, National Wetlands Research Center, 700

Cajundome Blvd., Lafayette, LA 70506, USA

S. P. Faulkner

U.S. Geological Survey, Leetown Science Center, 11649 Leetown

Road, Kearneysville, WV 25430, USA

Present Address:

S. C. Walls $(\bowtie)$

U.S. Geological Survey, Southeast Ecological Science Center, 7920

NW 71st Street, Gainesville, FL 32653, USA

e-mail: swalls@usgs.gov
Keywords Anuran amphibians · Conservation Effects Assessment Project · Cultivation · Occupancy · Species richness · USDA-NRCS Wetland Reserve Program · Wetland restoration

\section{Introduction}

Agricultural cultivation is a key contributor to wetland loss and alteration which, in turn, negatively impacts wetlanddependent species and ecosystem functioning (Gibbons et al. 2006). Worldwide, an estimated half of the total wetland area has been lost due to human activities, principally that of drainage in agricultural regions (Zedler and Kercher 2005). When drained, many of the ecosystem services these wetlands performed are lost or seriously degraded (Zedler 2003). In many areas, small, depressional wetlands suffer the greatest agriculture-related impacts and account for the vast majority of historical wetland loss (McCauley and Jenkins 2005; Gibbons et al. 2006; Blann et al. 2009; Bartzen et al. 2010; Curado et al. 2011). Yet, these wetlands provide crucial ecosystem services - that of maintaining regional biodiversity and metapopulation connectivity for semi-aquatic species (Semlitsch and Bodie 1998). Whether conservation efforts can mitigate historical wetland loss and degradation, such as that associated with most agricultural crop production, has been debated. Wetland ecosystems and the biodiversity they harbor may be somewhat "resilient" to habitat alteration (Gibbons et al. 2006), although habitat modification and fragmentation are also thought to have created an "extinction debt" that will continue to fuel future biodiversity declines, even after existing threats are alleviated (Blann et al. 2009).

Amphibians are useful bioindicators of habitat quality and restoration success (Waddle 2006; Dixon et al. 2011; Guzy et al. 2012; Waddle et al. 2013). Worldwide, amphibians are experiencing the most severe population declines of all the 
vertebrate groups, primarily because of loss and modification of suitable habitat (Collins and Storfer 2003; Stuart et al. 2004, 2008; Becker et al. 2007; Gallant et al. 2007; Becker et al. 2010; Collins 2010). The loss of small, temporary (ephemeral) wetlands $(<0.40 \mathrm{ha})$, which typically have high amphibian abundance and species diversity, may be especially harmful to amphibian populations (Semlitsch 2000). Alteration of hydrologic cycles can reduce larval survival, and the fragmentation of natural habitats from timber harvesting, agriculture, roads, drainage canals and urban development inhibits dispersal of amphibians between adjacent wetlands and their upland habitats (Semlitsch 2000; Becker et al. 2007, 2010). Many terrestrial amphibians are sensitive to intensive forestry practices, such as clear-cutting, that eliminates shading and leaf litter, thus increasing soil surface temperature and reducing leaf litter moisture (Petranka 1998).

The Mississippi Alluvial Valley (MAV) is a region of the USA that has suffered dramatic transformation from a forested wetland ecosystem to one that is currently "dominated by agriculture with forested wetlands embedded within an agricultural matrix" (King et al. 2006). Historically, the MAV was the largest bottomland hardwood forest (BLH) ecosystem in North America and provided extensive wetland habitat for many species (King et al. 2006). Today, no more than $25 \%$ of the original BLH remains (Rudis 1995; Twedt and Loesch 1999; King et al. 2006). The large-scale conversion of forests to cropland in the MAV resulted in a significant loss of wildlife habitat (MacDonald et al. 1979). In 1990, the need to restore and protect wetland ecosystem services and functions in agriculturally-dominated landscapes (such as the MAV) was addressed with the establishment of the Wetlands Reserve Program (WRP), administered by the U.S. Department of Agriculture's Natural Resources Conservation Service (USDA-NRCS). In 2003, the USDA-NRCS initiated the Conservation Effects Assessment Project, designed to evaluate whether USDA conservation programs were meeting program restoration objectives on private lands (Brinson and Eckles 2011). The WRP is the dominant program engaged in wetland restoration with participating private landowners within the MAV (Faulkner et al. 2011). Wetland restoration and creation are beneficial for many aquatic-breeding amphibians (e.g. Korfel et al. 2010; Lesbarrères et al. 2010; Shulse et al. 2010; Brown et al. 2012; Shulse et al. 2012), but few studies have directly addressed the responses of amphibians to restoration associated with conservation programs (Faulkner et al. 2011; Balas et al. 2012; Waddle et al. 2013).

We quantified the effects of conservation practices on anuran amphibians (frogs and toads) for wetlands enrolled in the WRP within the MAV. We monitored calling anurans at wetlands that had been restored through the WRP, as well as at wetlands situated in active cultivated cropland and mature bottomland hardwood forest. We estimated the proportion of cropland, restored and forested sites occupied for each anuran species detected and estimated total anuran species richness at each site. Compared to cultivated cropland sites, we anticipated that anuran occupancy and species richness would be greater at both WRP and forested sites.

\section{Methods}

\section{Study Sites}

We conducted our study in two watersheds within the MAV: the Tensas River Basin of Louisiana, USA (Madison, Tensas and Franklin Parishes) and the lower White and Cache River Basins of Arkansas (White, Woodruff, Prairie, Monroe, Phillips and St. Francis Counties). The Arkansas locations were within and/or adjacent to the Big Woods ecosystem, an area that comprises one of the largest remaining stands of bottomland hardwood forests in the southeastern USA (The Nature Conservancy 2013). We used spatially explicit GIS data (supplied by USDA-NRCS and the Farm Service Agency; USDA-FSA) that documented the location of WRP projects and randomly selected 16 sites in each of three habitat types: cultivated cropland (CC sites), former cropland reforested under the USDA-NRCS-WRP (WRP sites), and mature bottomland hardwood forest (BLH sites). The 48 sites collectively represented a habitat gradient that ranged from highly altered (CC), to relatively unaltered sites (WRP and BLH). The BLH sites were selected from sites with existing records and on-site evaluations indicating that the overstory vegetation was at least 70 years old and naturally regenerated. Half of the study sites occurred in the Tensas River Basin $(n=$ 24) and half occurred in the lower White/Cache River Basins ( $n=24$; Fig. 1). Each study site was $>40$ ha in size, $>100 \mathrm{~m}$ from the habitat edge, and $>400 \mathrm{~m}$ from a paved road. We maintained at least $4 \mathrm{~km}$ between WRP sites to avoid confounding landscape attributes that were to be used in a separate analysis of the effects of landscape features on restored ecosystem services. Crops at cultivated sites included Soybean (Glycine max), Corn (Zea mays), Milo (Sorghum bicolor), and Cotton (Gossypium hirsutum). The WRP sites were all planted between 1995 and 2004. The majority of tree species planted were Oaks: Nuttall (Quercus texana), Willow (Q. phellos), Water (Q. nigra), Overcup (Q. lyrata), Pin $(Q$. palustris), Shumard (Q. shumardii), Cherrybark (Q. pagoda), and Swamp Chestnut (Q. michauxii) (USDA-NRCS, unpubl. data). Other species included Green Ash (Fraxinus pennsylvanica), Baldcypress (Taxodium distichum), Sweet Pecan (Carya illinoensis), Persimmon (Diospyros virginiana), Sweetgum (Liquidambar styraciflua), Hackberry (Celtis laevigata), and Black Gum (Nyssa sylvatica) (USDA-NRCS, unpubl. data). All WRP sites had undergone some form of hydrologic restoration. In Louisiana, all but two of the BLH sites occurred on public land in the 
Tensas River National Wildlife Refuge and the Buckhorn and Big Lake Wildlife Management Areas. In Arkansas, all of the BLH sites were on public land (i.e. Cache and White River National Wildlife Refuges).

\section{Amphibian Monitoring}

We quantified anuran occurrence and species richness using remote automated digital recorders that recorded vocalizations of frogs and toads at each of our 48 study sites. Recording units consisted of Toshiba model e805 and Dell Axim ${ }^{\mathrm{TM}}$ model X50v personal digital assistants (PDAs) operated by software developed in-house using the .Net framework (for use with the Windows Mobile 2003 operating system). This software scheduled the timing of recordings and triggered an external omnidirectional microphone to operate at userselected intervals and durations. Each PDA was powered by 3 Power Sonic ${ }^{\circledR}$ 12-volt, 7 amp-hour sealed lead acid batteries. The PDA and batteries were housed in a water-tight Pelican Hardigg ${ }^{\mathrm{TM}}$ Storm Case $^{\mathrm{TM}}\left(33 \times 24 \times 15 \mathrm{~cm}\right.$, Pelican ${ }^{\mathrm{TM}}$ Products, Inc., San Antonio, TX) lined with pre-cut, nonabsorbent foam, and fitted with a microphone plug to accommodate the external microphone. We deployed a recorder, mounted on a wooden stand approximately $1.5 \mathrm{~m}$ above the ground, at each site and programmed them to record for $1 \mathrm{~min}$ at the beginning of every hour, from 1900 to $0300 \mathrm{~h}$ each night. Each site was visited every 20 days to maintain recording units, change batteries and retrieve recorded data.

We obtained recordings from 25 February 2007 to 30 June 2007, a period of 18 weeks. We used a week as our temporal (repeat) sampling unit for occupancy analysis. None of the recorders functioned continuously during the entire 18-week sample period, and often a recorder only functioned during part of a week. We defined a recorder as functional during a week if at least one full night of recordings was made during the week. We thus had 3-15 samples (mean=10.6) of each of the 48 sites. All of the 21,037 1-min digital audio files were listened to by an expert listener (i.e. a person with extensive knowledge of species-specific vocalizations of anuran amphibians from the South Central U.S. and experience in identifying those calls) using a desktop computer with noisecanceling headphones to identify all of the calling anurans audible in the recordings. Cumulative rainfall during each sampling week was summarized using archived National Oceanic and Atmospheric Administration precipitation records from the nearest weather stations operating at that time (Fig. 1).

\section{Data Analysis}

We used the hierarchical model of community species occurrence (Dorazio et al. 2006; Kéry and Royle 2008; Royle and Dorazio 2008) to estimate the site occupancy probability of anurans at sites by land-use category. This model, like other occupancy models, assumes that sites are sampled on $>1$ repeat visits during a period where sites are closed to changes in occupancy (MacKenzie et al. 2006). We believe the closure assumption is feasible in this case because it is unlikely that any sites would change occupancy status in the relatively short period of the study and because the anurans in this study have known calling periods that overlap nearly or completely with the study period (Dundee and Rossman 1989). The differences among species in estimates of detection probability $(p)$ and probability of occurrence $(\psi)$ are modeled with a normal distribution, such that each species in the community has an individual response to covariates (Royle and Dorazio 2008). The advantage of this community-level approach is that it provides a parsimonious method for obtaining occupancy estimates for multiple species, including rarely encountered ones. Estimates of species richness at the level of site or landuse category also are easily derived with this model (Royle and Dorazio 2008).

We modeled the effect of land-use category on occurrence of species (i) at each site (k) using the logit link (MacKenzie et al. 2006; Royle and Dorazio 2008) with the equation: $\operatorname{logit}\left(\psi_{i k}\right)=\beta 0_{i}+\beta 1_{i} \mathrm{WRP}_{k}+\beta 2_{i} \mathrm{BLH}_{k}$. Cultivated cropland sites take the value 0 for both WRP and BLH and are therefore modeled as the intercept $(\beta 0)$ alone. WRP and BLH sites are modeled with the intercept and a slope representing the effect of a site being in those categories relative to cultivated cropland. We hypothesized that the detection of calling anurans could be affected by rainfall during a sampling week, the number of days during a week that the recorder was working (hereafter effort), and the time of year of the sampling week (taken as the Julian date of the middle day of each week). Rainfall and effort were modeled as a linear effect and day was modeled as a quadratic effect on the detection probability of the anuran species. All covariates were standardized to have mean $=0$. The logit of the detection probability $(p)$ for a species (i) at any sample (j) of a site (k) is: $\operatorname{logit}\left(p_{i j k}\right)=\alpha 0_{i}+$ $\alpha 1_{i}$ Rainfall $_{j k}+\alpha 2_{i}$ Effort $_{j k}+\alpha 3_{i}$ Date $_{j k}+\alpha 4_{i}$ Date $_{j k}$.

We performed a Bayesian model selection routine following the methods of Kuo and Mallick (1998) as described in Royle and Dorazio (2008) to determine the model with the most weight among the models available by including and removing the covariates for the $\psi$ and $p$ parameters. Priors on the inclusion parameters in our model selection were distributed binomial with 0.5 probability (i.e. priors were non informative). We derived estimates of the site and land use-level species richness of anurans based on the values of the occupancy state variable for each species (Royle and Dorazio 2008). The model was fit using Markov-chain Monte Carlo (MCMC) methods in Program WinBUGS (Spiegelhalter et al. 2003), and convergence of parameters was assessed using the R-hat potential scale reduction values (Gelman and Hill 2007). Results are reported from the mean and $95 \%$ 


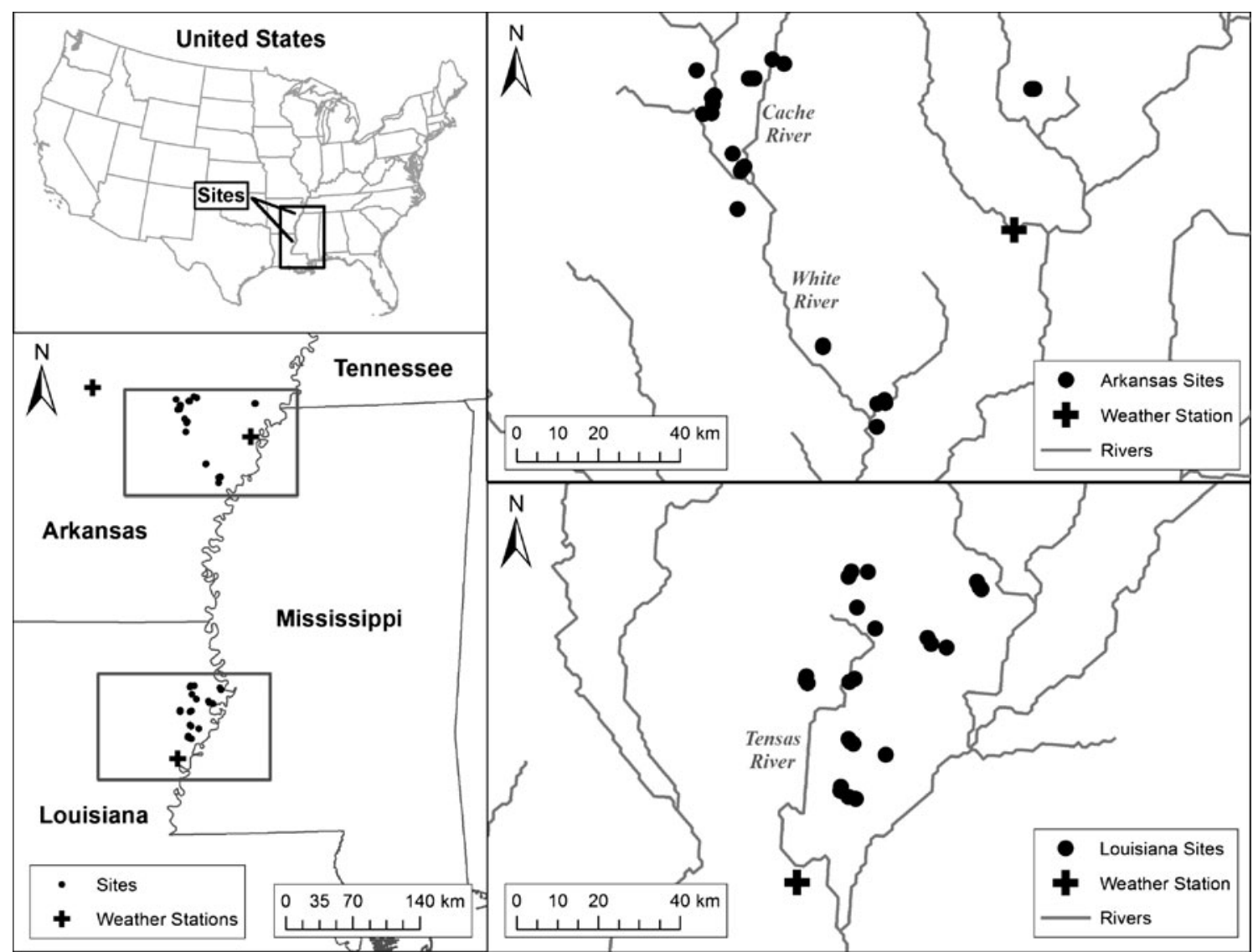

Fig. 1 Locations of study sites in the Tensas River Basin of Louisiana and the lower White and Cache River Basins of Arkansas, USA. Symbols represent sites at which automated recorders were deployed to monitor calling anuran amphibians, as well as locations of weather stations from which archived National Oceanic and Atmospheric Administration precipitation records were used to derive cumulative rainfall during each sampling week

Treefrog (Hyla avivoca) (Fig. 2). Detection probabilities also varied by Julian date. Several species detected had distinctly different seasons of calling activity, which reflects the natural breeding phenologies of these species (Fig. 3).

Minimum occupancy of each species, defined as the proportion of sampled sites where a species was detected on at least one occasion (Waddle et al. 2013), varied from 0.0 to 0.56 at CC sites; from 0.0 to 0.81 at WRP sites, and from 0.06 to 0.81 at BLH sites (Table 1). Estimated probabilities of occurrence at $\mathrm{CC}$ sites ranged from 0.03 to 0.45 , indicating that all species had some probability of occurrence at these locations (Fig. 4). In contrast, estimated occupancy probabilities were generally higher at WRP (from 0.08 to 0.83 ) and BLH (0.18 to 0.84) sites (Fig. 4).

Estimates of $\beta$ parameters indicated that WRP and BLH had positive effects on all 11 species, suggesting higher probabilities of occurrence in both WRP and BLH relative to CC sites (Figs. 5 and 6). The WRP effect was statistically significant for nine of the 11 species (all but Bird-voiced and Squirrel Treefrog [H. squirella]; Fig. 5), whereas the BLH effect was significant for six species (Cope's Gray Treefrog [H. chrysoscelis]; Spring Peeper, Green Frog [Lithobates 
Table 1 Minimum (naïve) occupancy of 11 anuran amphibians detected at wetlands in three different land use categories as part of USDA-NRCS's Wetland Reserve Program in the Mississippi Alluvial Valley, USA

\begin{tabular}{|c|c|c|c|c|c|}
\hline \multirow[t]{2}{*}{ Species } & \multirow[t]{2}{*}{ Common name } & \multicolumn{3}{|c|}{ Naïve occupancy in: } & \multirow[t]{2}{*}{ Breeding habitat } \\
\hline & & $\mathrm{CC}$ & WRP & BLH & \\
\hline Acris blanchardi & Blanchard's Cricket Frog & 0.06 & 0.44 & 0.31 & $\begin{array}{l}\text { Mostly open permanent wetlands; prefers wetlands with algae, emergent } \\
\text { vegetation, and gently sloping shallow regions. Rare or absent at large } \\
\text { lakes, wide rivers, and polluted sites }\end{array}$ \\
\hline Anaxyrus fowleri & Fowler's Toad & 0.25 & 0.38 & 0.25 & $\begin{array}{l}\text { Wide range of sites with or without fish: shallow regions of permanent } \\
\text { ponds, flooded low areas, temporary ponds, farm ponds, roadside } \\
\text { ditches, quiet streams, lake shores, or along the shallows of rivers, and } \\
\text { impoundments. Permanent and semi-permanent sites are preferred }\end{array}$ \\
\hline $\begin{array}{l}\text { Gastrophryne } \\
\text { carolinensis }\end{array}$ & $\begin{array}{l}\text { Eastern Narrow-mouthed } \\
\text { Toad }\end{array}$ & 0.00 & 0.31 & 0.13 & $\begin{array}{l}\text { Wide-ranging, including temporary ponds, flooded pastures and other } \\
\text { open grassy habitats, shallow depressions in open fields, rain-filled } \\
\text { ditches, edges of semi-permanent and permanent ponds and lakes, and } \\
\text { various human-created impoundments. Open wetlands without fish } \\
\text { are preferred }\end{array}$ \\
\hline Hyla avivoca & Bird-voiced Treefrog & 0.00 & 0.00 & 0.19 & $\begin{array}{l}\text { Hardwood swamps, river bottomlands and forested flood-plains, } \\
\text { especially those with cypress (Taxodium distichum) and tupelo gum } \\
\text { (esp. Nyssa aquatica) trees }\end{array}$ \\
\hline Hyla chrysoscelis & Cope's Gray Treefrog & 0.13 & 0.31 & 0.81 & $\begin{array}{l}\text { Shallow ponds and pools (permanent or temporary), either natural or } \\
\text { created, which can be highly disturbed. Known to breed in rain-filled } \\
\text { furrows of cornfields, open pools in flooded fields, road ruts, flooded } \\
\text { ditches, stormwater retention ponds and other artificial wetlands. } \\
\text { Avoids sites with fish }\end{array}$ \\
\hline Hyla cinerea & Green Treefrog & 0.56 & 0.75 & 0.69 & $\begin{array}{l}\text { Adaptable to a number of habitats including swamps, sloughs, marshes, } \\
\text { ponds, and lakes. Typically associated with permanent bodies of water } \\
\text { containing abundant subsurface, floating, emergent and shoreline } \\
\text { vegetation. Readily breeds in created wetlands. May occur with fish }\end{array}$ \\
\hline Hyla squirella & Squirrel Treefrog & 0.13 & 0.13 & 0.06 & $\begin{array}{l}\text { Preferentially breeds in small temporary woodland or pasture wetlands, } \\
\text { flooded roadside ditches, stock ponds, or other shallow bodies of } \\
\text { water. Does not normally breed in sites with fish. Adults show some } \\
\text { preference for open woodlands }\end{array}$ \\
\hline Lithobates catesbeianus & American Bullfrog & 0.06 & 0.69 & 0.44 & $\begin{array}{l}\text { Preferentially breeds in shallows of permanent bodies of water or semi- } \\
\text { permanent sites with long hydroperiods. Adept at colonizing newly } \\
\text { created ponds. Frequently found in agricultural and urban settings and } \\
\text { readily breeds in artificial impoundments. Has been found restricted to } \\
\text { open canopy ponds with permanent water and substantial, emergent } \\
\text { and submerged vegetation. Can coexist with predatory fishes }\end{array}$ \\
\hline Lithobates clamitans & Green Frog & 0.19 & 0.56 & 0.69 & $\begin{array}{l}\text { Wide array of sites, usually with long hydroperiods. Prefers permanent } \\
\text { aquatic habitats; shorelines of lakes and wetlands with emergent } \\
\text { vegetation, and streams, springs, quarries, farm ponds and other } \\
\text { anthropogenic sites }\end{array}$ \\
\hline $\begin{array}{l}\text { Lithobates } \\
\quad \text { sphenocephalus }\end{array}$ & Southern Leopard Frog & 0.13 & 0.81 & 0.25 & $\begin{array}{l}\text { Breeds in a wide variety of wetlands, both temporary and permanent, } \\
\text { natural and anthropogenic, with both open and closed canopies. } \\
\text { Prefers ponds without fish }\end{array}$ \\
\hline Pseudacris crucifer & Spring Peeper & 0.00 & 0.44 & 0.63 & $\begin{array}{l}\text { Uses many types of wetlands for breeding, both natural and artificial. } \\
\text { Prefers breeding sites with hydroperiods }>4 \text { months that are not } \\
\text { permanent. May be found with fish, but are more common in ponds } \\
\text { that lack predatory fish. Prefers open-canopied wetlands and can } \\
\text { disappear from breeding sites when the canopy closes over during } \\
\text { succession }\end{array}$ \\
\hline
\end{tabular}

Descriptions of breeding habitat are taken from Dodd (2013), and nomenclature follows that of Crother (2012)

$C C$ cultivated cropland sites; WRP former agricultural sites that have been restored through the USDA-NRCS Wetlands Reserve Program; and $B L H$ mature bottomland hardwood forested sites

clamitans], Bird-voiced Treefrog, American Bullfrog [L. catesbeianus], and Blanchard's Cricket Frog [Acris blanchardi]; Fig. 6). Estimated $\beta$ parameters were significantly higher for the effects of both WRP and BLH for five species (American Bullfrog, Spring Peeper, Blanchard's Cricket Frog, Green Frog, and Cope's Gray 


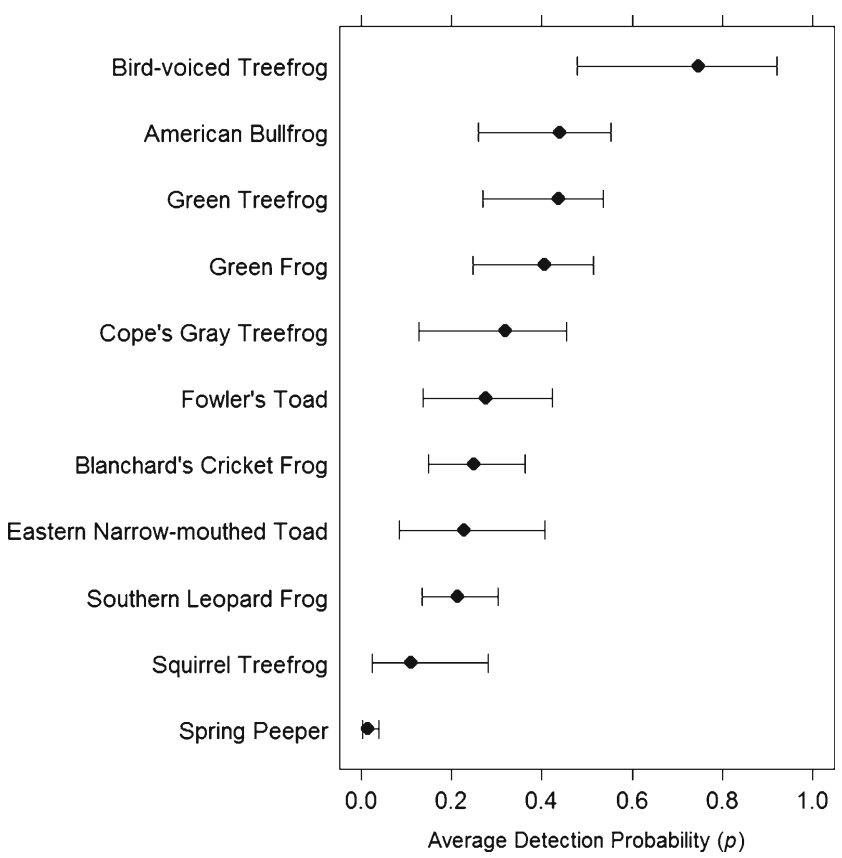

Fig. 2 Estimated average detection probability $(p)$ with $95 \%$ Bayesian credible interval for 11 anuran species

Treefrog; Figs. 5 and 6). Four species (Southern Leopard Frog [L. sphenocephalus], Eastern Narrow-mouthed Toad [Gastrophryne carolinensis], Green Treefrog [H. cinerea, and Fowler's Toad [Anaxyrus fowleri]) had $\beta$ parameter estimates that were significantly higher for the WRP effect only (Figs. 5 and 6). In contrast, a single species (Bird-voiced Treefrog) had a significantly higher estimated $\beta$ parameter for the effect of BLH, but not for that of WRP (Figs. 5 and 6). The Squirrel Treefrog had similar $\beta$ parameter estimates for all three land use categories (Figs. 5 and 6). Overall, there was an increasing trend in the estimated number of species per site for WRP and BLH sites, compared to CC sites. Estimates of species richness generally were highest in WRP, followed by BLH sites (Fig. 7). The average estimated species richness per

Fig. 3 Estimated detection probability $(p)$ for each of 11 anuran species during the sampling period (25 February 2007 to 30 June 2007)
Toads and Small Hylids

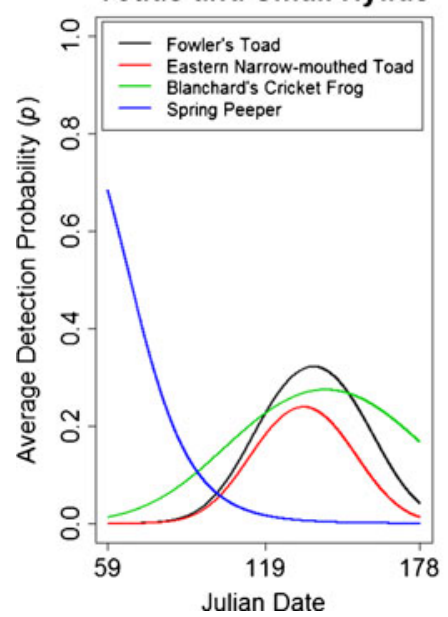

site was $1.25(s=1.34)$ for CC sites; $4.81(s=2.31)$ for WRP sites; and $4.06(s=2.15)$ for BLH sites.

\section{Discussion}

Our results illustrate that habitat restoration associated with the WRP had a positive effect (in terms of increased occupancy) on the majority ( $82 \%$ ) of amphibian species detected at our sites in the MAV. Relative to sites that were cultivated cropland, nine of the 11 species we detected (excluding the Bird-voiced and Squirrel Treefrogs) were significantly more likely to occur at WRP sites, whereas six species were significantly more likely to occur in forested than at cropland sites (Cope's Gray and Bird-voiced Treefrogs, Spring Peeper, Green Frog, American Bullfrog, and Blanchard's Cricket Frog). Compared to cropland sites, estimates of species richness were generally highest in WRP, followed by BLH sites. Four patterns emerged in species' responses to habitat type (relative to cultivated cropland): (1) four species (Southern Leopard Frog, Eastern Narrow-mouthed Toad, Green Treefrog, and Fowler's Toad) had higher occupancy estimates at WRP sites only; (2) the Bird-voiced Treefrog had a higher occupancy estimate in forested sites only; (3) the Squirrel Treefrog had similar estimates of occurrence in all three land use categories; and (4) five species (American Bullfrog, Spring Peeper, Blanchard's Cricket Frog, Green Frog, and Cope's Gray Treefrog) had similar estimates of occurrence in both WRP and forested sites, indicating that restored sites provide habitat that is equivalent to forested sites for calling males of several anurans. Our results correspond with known habitat associations of these species (Table 1; Lichtenberg et al. 2006) and indicate that patches undergoing restoration after cultivation may be an important transitional habitat for anuran species frequently associated with natural, forested wetlands. Although the relatively short term nature of our
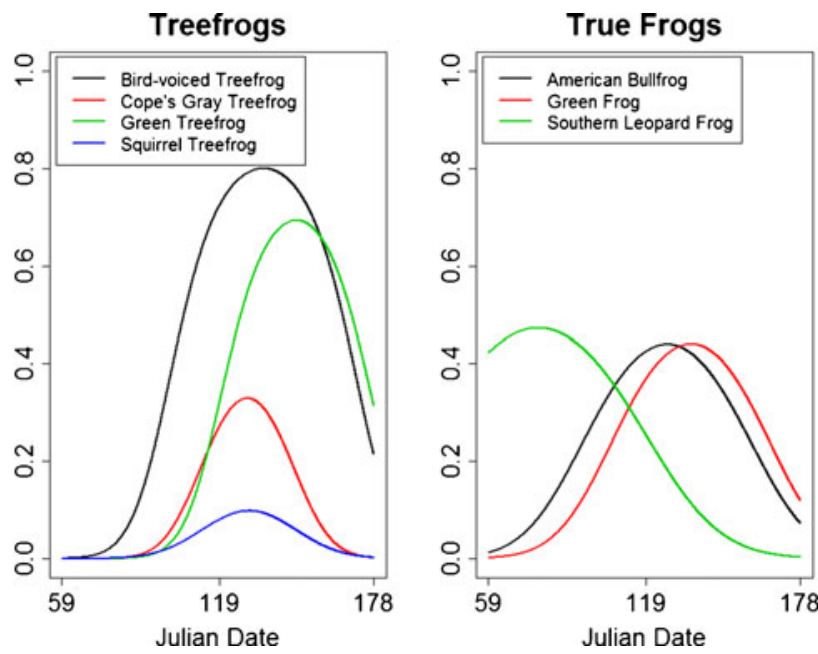
Fig. 4 Estimated probability of occurrence with $95 \%$ Bayesian credible intervals of 11 anuran species in each of the three landuse categories: cultivated cropland $(C C)$, Wetlands Reserve Program restored wetlands (WRP), and bottomland hardwood forest $(B L H)$

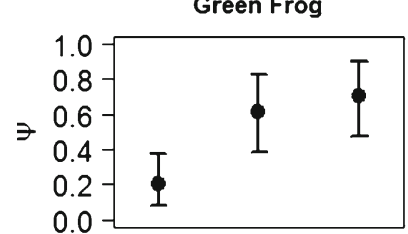

Blanchard's Cricket Frog

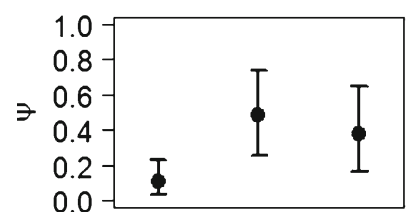

Fowler's Toad

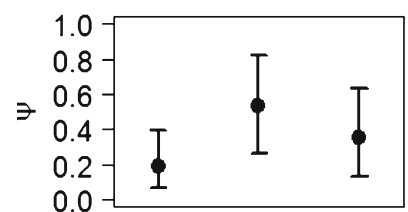

Bird-voiced Treefrog

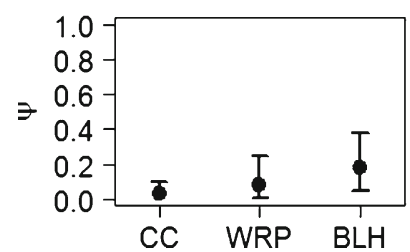

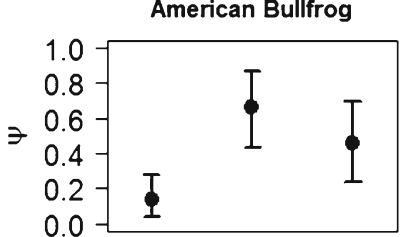

Spring Peeper

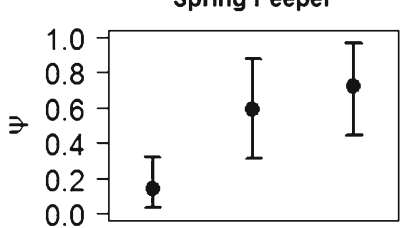

Eastern Narrow-mouthed Toac

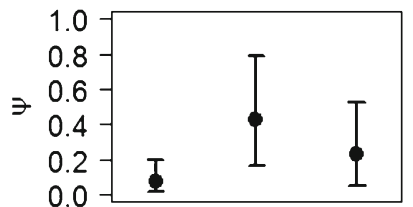

Squirrel Treefrog

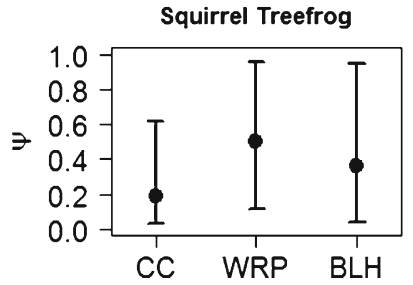

Cope's Gray Treefrog

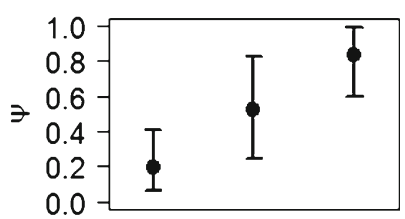

Green Treefrog

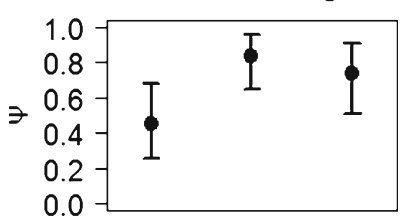

Southern Leopard Frog

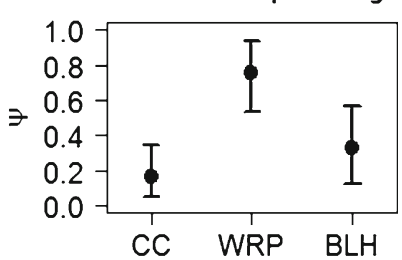

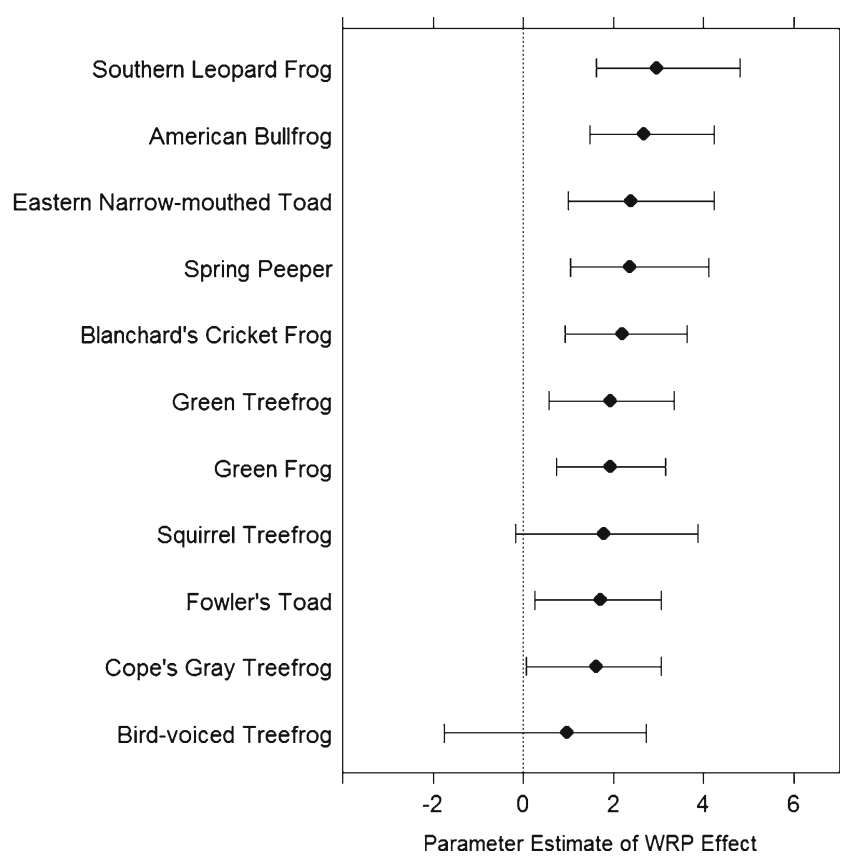

Fig. 5 Estimate of the beta parameter (logit scale) with $95 \%$ Bayesian credible interval of the effect of restoration $(W R P)$ relative to cultivated cropland $(C C)$ on occurrence of 11 anuran species. Credible intervals not including 0 are considered statistically significant at $\alpha=0.05$



Fig. 6 Estimate of the beta parameter (logit scale) with $95 \%$ Bayesian credible interval of the effect of bottomland hardwood forest $(B L H)$ relative to cultivated cropland $(C C)$ on occurrence of 11 anuran species. Credible intervals not including 0 are considered statistically significant at $\alpha=0.05$ 
Fig. 7 Observed and estimated (with $95 \%$ Bayesian credible intervals) species richness of anurans at each of the 16 sites within each land-use category (cultivated cropland $[C C]$, former cropland reforested under the USDA-NRCS-WRP [WRP], and bottomland hardwood forest $[B L H])$

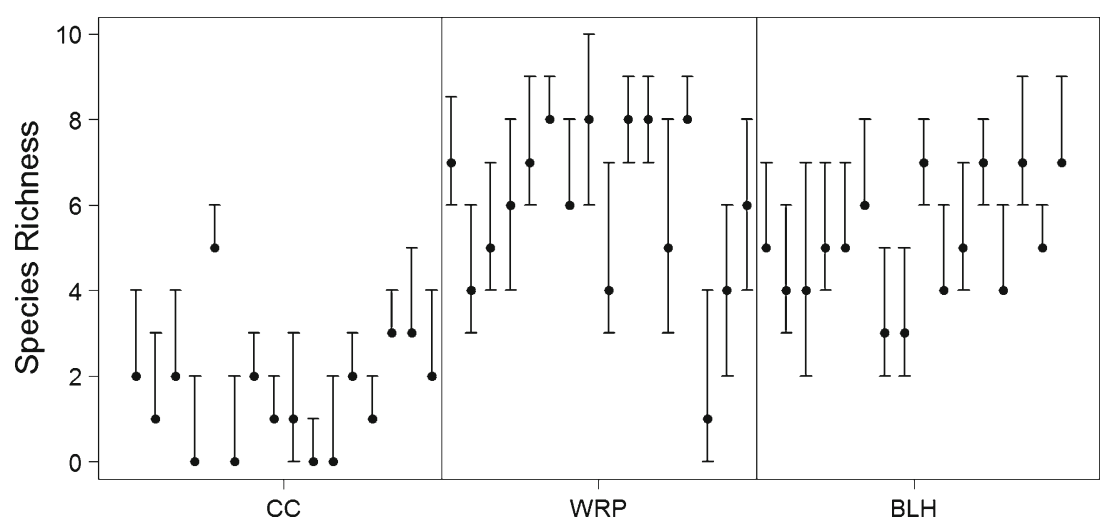

study may limit the scope of our inference somewhat, our results support the conclusion of other studies that conservation practices such as restoring wetlands under the WRP are successful in reducing the impact of cultivation-induced habitat loss on amphibian populations (Balas et al. 2012; Waddle et al. 2013).

\section{Amphibian Occurrence in Cultivated Cropland}

Our estimated probabilities of amphibian occurrence at CC sites indicated that all 11 species had some likelihood of occurring at these locations although, on average, estimates of site-level species richness in wetlands embedded within cultivated croplands were relatively low (1.25 species/site). The species most common at CC sites were the Green Treefrog, Fowler's Toad and Green Frog (naïve occupancies of $56 \%, 25 \%$, and $19 \%$, respectively), all of which are known to occupy a diversity of habitats, including "farm" and "stock" ponds (Table 1). Agricultural ponds are known to support amphibian populations in regions where natural breeding sites are scarce, despite their history of disturbance and lack of connection with neighboring wetlands due to habitat fragmentation (Knutson et al. 2004; Attademo et al. 2005). However, results from our study concur with many other studies that found reduced amphibian species richness in agricultural wetlands compared to natural sites, and increased species richness with greater wetland hydroperiod and adjacent land cover (Babbitt et al. 2005; 2006; Piha et al. 2007; Riedel et al. 2008; Babbitt et al. 2009; Venne et al. 2012). Amphibian persistence in agricultural areas is facilitated by drainage ditches and other riparian corridors which provide breeding sites and connectivity within an otherwise fragmented landscape (Maisonneuve and Rioux 2001; Jobin et al. 2004; Herzon and Helenius 2008; Maes et al. 2008; Purrenhage et al. 2009; Hartel et al. 2011; Faulkner et al. 2011, and references therein).
Amphibian Occurrence at Restored Versus Natural Forested Wetlands

Compared to cropland sites, four species (Southern Leopard Frog, Eastern Narrow-mouthed Toad, Green Treefrog, and Fowler's Toad) were significantly more likely to occur at WRP, but not BLH, sites. The higher occurrence of these four species in WRP sites may be a function of their affinities for several features of restored wetlands, including longer hydroperiods due to the presence of water control structures (Venne et al. 2012; Waddle et al. 2013); higher densities of herbaceous (as opposed to woody) plant cover around wetland margins, along with the presence of herbaceous leaf litter; and a lack of forest canopy (Guerry and Hunter 2002; Lichtenberg et al. 2006; Table 1). The extent of canopy cover over breeding ponds and the amount and composition of leaf litter in pond basins are factors that play a strong role in the distribution and abundance of some species of amphibians. The presence of canopy and composition of leaf litter and detritus may influence primary productivity, nutrient cycling, hypoxia and, consequently, larval development (Skelly et al. 2002; Halverson et al. 2003; Rubbo and Kiesecker 2004; Mokany et al. 2008; Williams et al. 2008; Sacerdote and King 2009; Maerz et al. 2010; Stephens et al. 2013). For example, in Michigan, litter from Green Ash - a tree species often planted at WRP sites in our study - significantly increased growth, development and survival of larval Wood Frogs (Lithobates sylvaticus), compared to litter composed of other tree species (Stephens et al. 2013). Moreover, in some amphibian populations the risk of disease caused by an emerging amphibian pathogen (the chytrid fungus, Batrachochytrium dendrobatidis) is higher at closed-canopy sites (Becker et al. 2012). Thus, wetlands with extensive canopy cover may be a deterrent to occupancy by several species of anurans.

Five of the 11 species detected (American Bullfrog, Spring Peeper, Blanchard's Cricket Frog, Green Frog, and Cope's Gray Treefrog) had similar estimates of occurrence in both 
restored and forested sites. Four of these species (all but Blanchard's Cricket Frog) have been found primarily or exclusively in open-canopy wetlands in other regions (Skelly et al. 1999; Binckley and Resetarits 2007; Felix et al. 2010). In the MAV, the American Bullfrog, Green Frog, and Blanchard's Cricket Frog are associated with permanent or long hydroperiod sloughs and large swale wetlands that have large patches of open water. Woody plant cover and litter are important habitat features for Cope's Gray Treefrog, Spring Peeper, American Bullfrog and Green Frog (Lichtenberg et al. 2006; Table 1). These features may be characteristic of forested wetlands, and late-stage restoration sites that offer some or all of these conditions likely provide suitable habitat for these species as well.

The Bird-voiced Treefrog was restricted to forested sites in our study. This species is highly specific to mostly permanent Baldcypress and Tupelo Gum (esp. Nyssa aquatica) fluvial swamps (e.g. oxbow lakes formed from large rivers: MartínezRivera and Gerhardt 2008), where woody shrubs such as Buttonbush (Cephalanthus spp.) provide perches for calling males over water (Fouquette and Delahoussaye 1966; Dundee and Rossman 1989; Fulmer and Tumlison 2004; Table 1). In their surveys in southwestern Arkansas, Fulmer and Tumlison (2004) found no Bird-voiced Treefrogs in areas with moderate to heavy agricultural activity. Given its habitat specificity, it is not surprising that we found Bird-voiced Treefrogs in forested sites only. In contrast, the Squirrel Treefrog had similar estimates of occurrence across all three land-use categories. This species has been regarded as a habitat generalist (Hether 2010), although females preferentially oviposit in wetlands with open canopy over those with closed canopy (Binckley and Resetarits 2007). Squirrel Treefrogs occupy a wide array of habitats, ranging from fields to pine and oak groves and open wooded areas (Wright and Wright 1933; Carr 1940; Hether 2010; Hether and Hoffman 2012; Table 1). Thus, this species is well-suited for occupying the diverse array of habitats encompassed by our study.

\section{Conservation Value of Restored WRP Wetlands}

Habitat loss and alteration pose the principle threats to global biodiversity, and conservation programs such as the WRP may play a pivotal role in facilitating landscape-scale conservation of amphibians and other wetland-dependent wildlife on private and tribal lands. For example, by 2012 the WRP had successfully enrolled more than 930,000 ha of land in the USA by providing landowners compensation and technical assistance for voluntarily participating in conservation easements (USDA-NRCS 2013). Some have asserted that restored (and, by extension, created) wetlands often do not attain the biodiversity, ecological function, and sustainability of natural systems (Zedler 2003; Moreno-Mateos et al. 2012). In a study not affiliated with the WRP, created vernal pools did not mimic natural pools in several physiochemical and hydrological attributes 11 years after construction (Korfel et al. 2010). If the measures of restoration success are primarily chemical and hydrologic characteristics, then attempts to replicate historic conditions may not be feasible or ultimately successful. Nevertheless, the created pools studied by Korfel et al. (2010) had greater taxonomic evenness and diversity, and were as productive (in terms of amphibian biomass) as natural pools. By extension, restoration goals that focus on the production of resilient, functional ecosystems under the guidance of established ecological principles may have a much greater likelihood of success (Thorpe and Stanley 2011).

Successful amphibian colonization of restored and created wetlands following degradation or destruction of natural habitats implies that wetland ecosystems may be somewhat resilient to anthropogenic activities such as conversion to cultivated cropland and road construction (Gibbons et al. 2006; Lesbarrères et al.2010). Using amphibians as indicators of restoration success, Balas et al. (2012) and Waddle et al. (2013) demonstrated the effectiveness of conservation practices implemented under the WRP, and the results of the present study support their findings. Amphibian populations are declining at an alarming rate on public lands in the USA (Adams et al. 2013), but the status of amphibians is currently unknown on the nearly $60 \%$ of land in the United States that is privately owned (Nickerson et al. 2011; Meyer et al. 2012). Thus, conservation programs that target privately-owned lands are especially well-poised to promote private land stewardship and advance amphibian conservation by counteracting wetland losses due to agricultural cultivation.

Acknowledgments We thank the private landowners for access to their property, and the following USDA-NRCS employees who contacted landowners and helped coordinate our project in their areas: A. Bridgewater, J. Jenkins, M. Tidwell, D. Fowlkes, and R. Childress. D. Eckles provided much advice and support. M. Baldwin and P. Bhattarai helped evaluate and locate study sites. M. Baldwin, J. Beck, P. Bhattarai, C. Case, W. Hedge, S. Hill, S. Hunnicutt and T. Trahan assisted with field work. J. Beck listened to all recordings and made all species identifications. J. Sullivan designed and assembled the ARU's and R. Putnam developed the recorder software. M. Melder, M. Silva and J. Richard helped with other ARU issues. We are grateful to J. Barichivich, S. Bostick, M. Brown, and C. Smith for their help in proofing the database, and B. Glorioso for preparing Fig. 1. We thank K. Haag and J. Mitchell for reading an earlier draft of the manuscript. Personnel at Buckhorn Wildlife Management Area, Tensas River, Cache River and White River National Wildlife Refuges granted permission to work in these areas. This study was funded by USDA-NRCS and the U.S. Geological Survey's Amphibian Research and Monitoring Initiative (USGS-ARMI). Any use of trade, product, or firm names is for descriptive purposes only and does not imply endorsement by the U.S. Government. This is contribution number 459 of USGS-ARMI. 


\section{References}

Adams MJ, Miller DAW, Muths E, Corn PS, Grant EHC, Bailey LL, Fellers GM, Fisher RN, Sadinski WJ, Waddle H, Walls SC (2013) Trends in amphibian occupancy in the United States. PLoS ONE 8: e64347. doi:10.1371/journal.pone.0064347

Attademo AM, Peltzer PM, Lajmanovich RC (2005) Amphibians occurring in soybean and implications for biological control in Argentina. Agric Ecosyst Environ 106:389-394

Babbitt KJ, Baber MJ, Tanner GW (2005) The impact of agriculture on temporary wetland amphibians in Florida. In: Meshaka WE Jr, Babbitt KJ (eds) Amphibians and reptiles: status and conservation in Florida. Krieger, Malabar, pp 48-55

Babbitt KJ, Baber MJ, Brandt LA (2006) The effect of woodland proximity and wetland characteristics on larval anuran assemblages in an agricultural landscape. Can J Zool 84:510-519

Babbitt KJ, Baber JM, Childers DL, Hocking D (2009) Influence of agricultural upland habitat type on larval anuran assemblages in seasonally inundated wetlands. Wetlands 29:294-301

Balas CJ, Euliss NH Jr, Mushet DM (2012) Influence of conservation programs on amphibians using seasonal wetlands in the Prairie Pothole Region. Wetlands 32:333-345

Bartzen BA, Dufour KW, Clark RG, Caswell FD (2010) Trends in agricultural impact and recovery of wetlands in prairie Canada. Ecol Appl 20:525-538

Becker CG, Fonseca CR, Haddad CFB, Batista RF, Prado PI (2007) Habitat split and the global decline of amphibians. Science 318: $1775-1777$

Becker CG, Fonseca CR, Haddad CFB, Batista RF, Prado PI (2010) Habitat split as a cause of local population declines of amphibians with aquatic larvae. Conserv Biol 24:287-294

Becker CG, Rodriguez D, Longo AV, Talaba AL, Zamudio KR (2012) Disease risk in temperate amphibian populations is higher at closedcanopy sites. PLoS ONE 7:e48205. doi:10.1371/journal.pone. 0048205

Binckley CA, Resetarits WJ Jr (2007) Effects of forest canopy on habitat selection in treefrogs and aquatic insects: implications for communities and metacommunities. Oecologia 153:951-958

Blann KL, Anderson JL, Sands GR, Vondracek B (2009) Effects of agricultural drainage on aquatic ecosystems: a review. Crit Rev Environ Sci Technol 39:909-1001

Brinson MM, Eckles SD (2011) U.S. Department of Agriculture conservation program and practice effects on wetland ecosystem services: a synthesis. Ecol Appl 21:S116-S127

Brown DJ, Street GM, Nairn RW, Forstner MR (2012) A place to call home: amphibian use of created and restored wetlands. International Journal of Ecology 2012: Article ID 989872, 11 pp. doi:10.1155/ 2012/989872

Carr AF (1940) Dates of frog choruses in Florida. Copeia 1940:55

Collins JP (2010) Amphibian decline and extinction: what we know and what we need to learn. Dis Aquat Org 92:93-99

Collins JP, Storfer A (2003) Global amphibian declines: sorting the hypotheses. Divers Distrib 9:89-98

Crother BI (ed) (2012) Scientific and standard English and French names of amphibians and reptiles of North America north of Mexico, with comments regarding confidence in our understanding. Society for the Study of Amphibians and Reptiles Herpetological Circular 39:192, Shoreview

Curado N, Hartel T, Arntzen JW (2011) Amphibian pond loss as a function of landscape change - a case study over three decades in an agricultural area of northern France. Biol Conserv 144:1610 1618

Dixon AD, Cox WR, Everham EM III, Ceilley DW (2011) Anurans as biological indicators of restoration success in the Greater Everglades ecosystem. Southeast Nat 10:629-646
Dodd CK Jr (2013) Frogs of the United States and Canada, vol 1 and 2. John Hopkins, Baltimore

Dorazio RM, Royle JA, Söderström B, Glimskär A (2006) Estimating species richness and accumulation by modeling species occurrence and detectability. Ecology 87:842-854

Dundee HA, Rossman DA (1989) The amphibians and reptiles of Louisiana. Louisiana State University Press, Baton Rouge

Faulkner S, Barrow W Jr, Keeland B, Walls S, Telesco D (2011) Effects of conservation practices on wetland ecosystem services in the Mississippi Aluvial Valley. Ecol Appl 21:S31-S48

Felix ZI, Wang Y, Schweitzer CJ (2010) Effects of experimental canopy manipulation on amphibian egg deposition. J Wildl Manag 74:496503

Fouquette MJ Jr, Delahoussaye AJ (1966) Noteworthy herpetological records from Louisiana. Southwest Nat 11:137-139

Fulmer T, Tumlison R (2004) Important records of the Bird-Voiced Treefrog (Hyla avivoca) in the headwaters of the Ouachita River Drainage of Southwestern Arkansas. Southeast Nat 3:259-266

Gallant AL, Klaver RW, Casper GS, Lannoo MJ (2007) Global rates of habitat loss and implications for amphibian conservation. Copeia 2007:967-979

Gelman A, Hill J (2007) Data analysis using regression and multilevel/ hierarchical models. Cambridge University Press, New York

Gibbons JW, Winne CT, Scott DE, Willson JD, Glaudas X, Andrews KM, Todd BD, Fedewa LA, Wilkinson L, Tsaliagos RN, Harper SJ, Greene JL, Tuberville TD, Metts BS, Dorcas ME, Nestor JP, Young CA, Akre T, Reed RN, Buhlmann KA, Norman J, Croshaw DA, Hagen C, Rothermel BB (2006) Remarkable amphibian biomass and abundance in an isolated wetland: implications for wetland conservation. Conserv Biol 20:1457-1465

Guerry AD, Hunter ML Jr (2002) Amphibian distributions in a landscape of forests and agriculture: an examination of landscape composition and configuration. Conserv Biol 16:745-754

Guzy JC, McCoy ED, Deyle AC, Gonzalez SM, Halstead N, Mushinsky HR (2012) Urbanization interferes with the use of amphibians as indicators of ecological integrity of wetlands. J Appl Ecol 49:941952

Halverson MA, Skelly DK, Kiesecker JM, Freidenburg LK (2003) Forest mediated light regime linked to amphibian distribution and performance. Oecologia 134:360-364

Hartel T, Băncila R, Cogălniceanu D (2011) Spatial and temporal variability of aquatic habitat use by amphibians in a hydrologically modified landscape. Freshw Biol 56:2288-2298

Herzon I, Helenius J (2008) Agricultural drainage ditches, their biological importance and functioning. Biol Conserv 141:1171-1183

Hether, TD (2010) Using landscape genetics to assess population connectivity in a habitat generalist. Unpubl. MS thesis, University of Central Florida, Orlando, Florida

Hether TD, Hoffman EA (2012) Machine learning identifies specific habitats associated with genetic connectivity in Hyla squirella. J Evol Biol 25:1039-1052

Jobin B, Bélanger L, Boutin C, Maisonneuve C (2004) Conservation value of agricultural riparian strips in the Boyer River watershed, Québec (Canada). Agric Ecosyst Environ 103:413-423

Kéry M, Royle JA (2008) Hierarchical Bayes estimation of species richness and occupancy in spatially replicated surveys. J Appl Ecol 45:589-598

King SL, Twedt DJ, Wilson RR (2006) The role of the Wetland Reserve Program in conservation efforts in the Mississippi River Alluvial Valley. Wildl Soc Bull 34:914-920

Knutson MG, Richardson WB, Reineke DM, Gray BR, Parmelee JR, Weick SE (2004) Agricultural ponds support amphibian populations. Ecol Appl 14:669-684

Korfel CA, Mitsch WJ, Hetherington TE, Mack JJ (2010) Hydrology, physiochemistry, and amphibians in natural and created vernal pool wetlands. Restor Ecol 18:843-854 
Kuo L, Mallick B (1998) Variable selection for regression models. Sankhya 60B:65-81

Lesbarrères D, Fowler MS, Pagano A, Lodé T (2010) Recovery of anuran community diversity following habitat replacement. J Appl Ecol 47: $148-156$

Lichtenberg JS, King SL, Grace JB, Walls SC (2006) Habitat associations of chorusing anurans in the Lower Mississippi River Alluvial Valley. Wetlands 26:736-744

MacDonald PO, Frayer WE, Clauser JK (1979) Documentation, chronology, and future projections of bottomland hardwood habitat loss in the lower Mississippi Alluvial Plain, v. 1, Basic Report: Washington, D.C., U.S. Fish and Wildlife Service, Ecological Services

MacKenzie DI, Nichols JD, Royle JA, Pollock KH, Bailey LL, Hines JE (2006) Occupancy estimation and modeling: inferring patterns and dynamics of species occurrence. Academic, Burlington

Maes J, Musters CJM, De Snoo GR (2008) The effect of agrienvironment schemes on amphibian diversity and abundance. Biol Conserv 141:635-645

Maerz JC, Cohen JS, Blossey B (2010) Does detritus quality predict the effect of native and non-native plants on the performance of larval amphibians? Freshw Biol 55:1694-1704

Maisonneuve C, Rioux S (2001) Importance of riparian habitats for small mammal and herpetofaunal communities in agricultural landscapes of southern Québec. Agric Ecosyst Environ 83:165-175

Martínez-Rivera CC, Gerhardt HG (2008) Advertisement-call modification, male competition, and female preference in the Bird-Voiced Treefrog Hyla avivoca. Behav Ecol Sociobiol 63:195-208

Meyer SR, Johnson ML, Lilieholm RJ (2012) Land conservation in the United States: evolution and innovation across the urban-rural interface. In: Laband DN, Lockaby BG, Zipperer W (eds) Urbanrural interfaces: linking people and nature. American Society of Agronomy, Soil Science Society of America, Crop Science Society of America, Madison, pp 225-255

McCauley LA, Jenkins DG (2005) GIS-based estimates of former and current depressional wetlands in an agricultural landscape. Ecol Appl 15:1199-1208

Mokany A, Wood JT, Cunningham SA (2008) Effect of shade and shading history on species abundances and ecosystem processes in temporary ponds. Freshw Biol 53:1917-1928

Moreno-Mateos D, Power ME, Comín FA, Yockteng R (2012) Structural and functional loss in restored wetland ecosystems. PLoS Biol 10: e1001247. doi:10.1371/journal.pbio.1001247

Nickerson C, Ebel R, Borchers A, Carriazo F (2011) Major uses of land in the United States, 2007, EIB-89, U.S. Department of Agriculture, Economic Research Service

Petranka JW (1998) Salamanders of the United States and Canada. Smithsonian Institution Press, Washington

Piha H, Luoto M, Merila J (2007) Amphibian occurrence is influenced by current and historic landscape characteristics. Ecol Appl 17:22982309

Purrenhage JL, Niewiarowski PH, Moore FB-G (2009) Population structure of spotted salamanders (Ambystoma maculatum) in a fragmented landscape. Mol Ecol 18:235-247

Riedel BL, Russell KR, Ford WM, O'Neill KP, Godwin HW (2008) Habitat relationships of eastern redbacked salamanders (Plethodon cinereus) in Appalachian agroforestry and grazing systems. Agric Ecosyst Environ 124:229-236

Royle JA, Dorazio RM (2008) Hierarchical modeling and inference in ecology. Academic, Amsterdam

Rubbo MJ, Kiesecker JM (2004) Leaf litter composition and community structure: translating regional species changes into local dynamics. Ecology 85:2519-2525
Rudis VA (1995) Regional forest fragmentation effects on bottomland hardwood community types and resource values. Landsc Ecol 10: 291-307

Sacerdote AB, King RB (2009) Dissolved oxygen requirements for hatching success of two ambystomatid salamanders in restored ephemeral ponds. Wetlands 29:1202-1213

Semlitsch RD (2000) Principles for management of aquatic-breeding amphibians. J Wildl Manag 64:615-631

Semlitsch RD, Bodie JR (1998) Are small, isolated wetlands expendable? Conserv Biol 12:1129-1133

Shulse CD, Semlitsch RD, Trauth DM, Williams AD (2010) Influences of design and landscape placement parameters on amphibian abundance in constructed wetlands. Wetlands 30:915-928

Shulse CD, Semlitsch RD, Trauth KM, Gardner JE (2012) Testing wetland features to increase amphibian reproductive success and species richness for mitigation and restoration. Ecol Appl 22:1675-1688

Skelly D, Werner E, Cortwright S (1999) Long-term distributional dynamics of a Michigan amphibian assemblage. Ecology 80:23262337

Skelly DK, Freidenburg LK, Kiesecker JM (2002) Forest canopy and the performance of larval amphibians. Ecology 83:983-992

Spiegelhalter DJ, Thomas A, Best NG, Lunn D (2003) WinBUGS version 1.4 user manual. MRC Biostatistics Unit, Cambridge

Stephens JP, Berven KA, Tiegs SD (2013) Anthropogenic changes to leaf litter input affect the fitness of a larval amphibian. Freshw Biol 58: $1631-1646$

Stuart SN, Chanson JS, Cox NA, Young BE, Rodrigues ASL, Fischmann DL, Waller RW (2004) Status and trends of amphibian declines and extinctions worldwide. Science 306:1783-1786

Stuart SN, Hoffmann M, Chanson JS, Cox NA, Berridge RJ, Ramani P, Young BE (2008) Threatened Amphibians of the World. Lynx Edicions, Barcelona, Spain; IUCN, Gland, Switzerland; Conservation International, Arlington

The Nature Conservancy (2013) Arkansas Big Woods: ecological significance and threats. http://www.nature.org/ourinitiatives/regions/ northamerica/unitedstates/arkansas/placesweprotect/big-woodsecological-significance-and-threats.xml. Accessed 13 May 2013

Thorpe AS, Stanley AG (2011) Determining appropriate goals for restoration of imperiled communities and species. J Appl Ecol 48:275-279

Twedt DJ, Loesch CR (1999) Forest area and distribution in the Mississippi alluvial valley: implications for breeding bird conservation. J Biogeogr 26:1215-1224

USDA-NRCS (2013) Restoring America's wetlands: a private lands conservation success story (http://www.nrcs.usda.gov/Internet/ FSE_DOCUMENTS/stelprdb1045079.pdf. Accessed 2 June 2013

Venne LS, Tsai J, Cox SB, Smith LM, McMurry ST (2012) Amphibian community richness in cropland and grassland playas in the southern High Plains, USA. Wetlands 32:619-629

Waddle JH (2006) Use of amphibians as ecosystem indicator species. Unpubl. Ph.D. Dissertation, University of Florida, Gainesville, Florida

Waddle JH, Glorioso BM, Faulkner SP (2013) A quantitative assessment of the conservation benefits of the Wetlands Reserve Program to amphibians. Restor Ecol 21:200-206

Williams BK, Rittenhouse TAG, Semlitsch RD (2008) Leaf litter input mediates tadpole performance across forest canopy treatments. Oecologia 155:377-384

Wright AH, Wright AA (1933) Handbook of frogs and toads of the United States and Canada. Comstock, Ithaca

Zedler JB (2003) Wetlands at your service: reducing impacts of agriculture at the watershed scale. Front Ecol Environ 1:65-72

Zedler JB, Kercher S (2005) Wetland resources: status, trends, ecosystem services, and restorability. Annu Rev Environ Resour 30:39-74 